\title{
Cooperative Models Practice Type Teams Games Tournaments (TGT) With a Saintific Approach on Material Opportunity
}

\author{
Adimas Eko Permadi, Yus Mochamad Cholily, Alfiani Athma Putri \\ Mathematics Education, Faculty of Teacher Training and Education \\ University of Muhammadiyah Malang \\ Email: adimaseko28@gmail.com
}

\begin{abstract}
This study aimed to describe learning plan on Opportunity material using Teams Games Tournaments (TGT) with a scientific approach, and to know student learning activities on learning materials opportunities using Teams Games Tournaments (TGT) with scientific approach, as well as to know the results of student learning on learning materials Opportunities using Teams Games Tournaments (TGT) with scientific approach. Type of this research is descriptive and the approach used is qualitative and quantitative. Technique of collecting data were observation, test, and documentation. The results showed that the planning of TGT learning was only based on 4 components: (1) class presentations, (2) teams, (3) games, and (4) tournaments as well as the non-implementation of group awards and components combined with scientific approaches, while student learning activities are in type of "good" category since the test results showed that 28 students were complete and 6 students were unfinished. In classical, students' completeness reached $82.3 \%$ and was said to be complete. These results indicated that learning activities with TGT model with scientific approach is good to be applied.
\end{abstract}

Keywords: Teams Games Tournaments (TGT), Scientific Approach, Learning Planning, Student Learning Activities, and Learning Outcomes.

\section{INTRODUCTION}

Mathematic is one of subject holding an important role in life. Mathematic is a tool which has been widely applied to facilitate, streamline and to efficient human works (Yuhasriati, 2012: 81). Therefore, mathematics is learned at every level of education from the basic to the highest level and each every level must be able to develop the potential of the students so then are able to understand mathematics correctly which is very useful to face life in the future.

Based on the results of observations of researchers in grade 8.5 SMP Negeri 5 Malang, researchers found that teachers were using group discussion method during the learning process in the classroom. As in discussion, students exchanged the tasks which was to be done by other group members. The exchanging tasks caused in a commotion and made the discussion process stunted. As the result, students would do the task by themself and sometimes others were just imitating and crowded themselves so that the learning process could not run as expected. At the end of the discussion, the teacher asked 
the students to rework the results of their discussion on the board, but students were embarrassed to come forward and eventually the teacher called forcibly to work on the board. Learning using discussion method was not wrong, but it needs to use variations of discussion to reduce the mutual throwing tasks and not even contribute to the group.

One of learning models that can be used to actively increase student participation in learning is by applying the Teams Games Tournamens (TGT). The TGT lesson emphasizes playing game to score the respective teams. The game can be arranged by teachers in the form of quiz consisted of questions related to learning materials (Rusman, 2012: 202). Students will not feel bored in the learning activities with game and will be active because they are required to obtain the score for their respective teams. The use of cooperative learning type TGT allows students to learn more relax, while the use of this learning model can foster responsibility, honesty, cooperation, fair competition and student involvement in learning (Sudarti, 2015: 179). According to Slavin (2009: 166) there are five main components in cooperative learning type Teams Games Tournaments (TGT): (1) class presentations, (2) teams, (3) games, (4) tournaments, and (5) group awards.

At the beginning of the TGT lesson, the teacher conveyes some questions of previous material, and delivered the subject matter. After that, the teacher divides the students into groups of 4 to 5 heterogeneous students. After the group activity is completed, the teacher creates a game consists of questions designed from the material that the teacher gave to the students to test the knowledge in order to represent each group in the tournament activities. A student represents the group picks up a numbered card and answers the question that matches the number on the card. Students who correctly answer the question will get score. This score should be collected to follow the tournament. Furthermore, in this tournament they will play an academic game that answers questions with relevant content to test students' knowledge of class presentations and teamwork. The game is played on a table with three or four students each representing the team. Students who correctly answered the question will get the score. This score is then collected by the students and summed up with the scores obtained by teammates to gain group awards. After the tournament ends, the teacher then announces the winning group, each team or group will get a certificate or prize if the average score meets a predetermined criteria. Team or group gets the nickname "Super Team" if the average score was 50 or more, "Great Team" if the average reaches 50-40 and "Good Team" if the background was 40 down.

Seeing that SMP Negeri 5 Malang isusing K-13 curriculum, the learning activities were implemented using a scientific approach or a science-based approach. The scientific approach includes 5M activities: observing, questioning, gathering information or trying, reasoning or associating, and communicating. The purpose of this research is to describe the learning plan, to know the student's learning activity, and to know the student's learning result on the learning of Opportunity using Teams Games Tournaments (TGT) with scientific approach in SMP Negeri 5 Malang. This study is based on the results of research which states that cooperative learning model of TGT type with scientific approach is one of the learning model that can be used to achieve optimal learning result (Ramadhana, 2015: 420). 


\section{RESEARCH METHODS}

The type of research used in this research are qualitative and quantitative research. This research was conducted in SMP Negeri 5 Malang academic year 2016-2017 in class 8.5 which consisted of 34 students. Activities undertaken in this research were planning, designing, executing, collecting data, drawing conclusions, and making reports. This research used data collection method are; (1) observation, (2) test, and (3) documentation. Observations were conducted to observe student learning activities during the learning process. Observations were made by the observer by filling in the obervation sheets provided. The test was used to determine student learning outcomes. Documentation was by photographing the learning activities.

This study used the following instruments: (1) Learning Implementation Plan (RPP), (2) observation sheets, (3) Group Worksheet (LKK), and (4) test. Learning Implementation Plan (RPP) was used as a guide or reference in carrying out learning activities. The RPP was made based on students learning time in school. Observation sheets were used to measure student learning activities with an observational format for student involvement during the learning process. The observation sheet used was adjusted to the activity indicator in the lesson. The Group Work Sheet (LKK) in this study was used as a discussion material for the students. LKK is a description of 3 questions at the first meeting and 2 questions at the second meeting. The test in this research is used to know the student learning outcomes. This test was a matter of description which consisted of 5 questions and used to know the results of student learning after the learning process. Data analysis used in this study was to calculate the average value of each indicator in the study.

\section{RESULTS AND DISCUSSION}

Before conducting the research activities, the researcher met the mathematics teacher discussing the research plan that will be implemented. In addition, the researchers also demonstrated the Learning Implementation Plan (RPP) that has been made to be studied directly by the teacher. The RPP had been adapted to the steps of preparing RPP which include writing: (1) identity of school / madrasah, subject, and class / semester; (2) time allocation; (3) KI, KD, indicators of competence achievement; (4) learning materials; (5) learning activities; (6) assessment; and (7) media / tools, materials, and learning resources (Permendikbud, 2013). Researchers plan TGT activities to focus on 4 components: (1) class presentation, (2) team, (3) game, and (4) tournament. This is based on the learning time at the school which has 40 minutes at each meeting and the TGT activities must be combined with a scientific approach that has 5 activities, are; (1) observing, (2) asking, (3) trying, (4) reasoning, and (communicating).

After reading the lesson plan, the teacher gives direction in the form of time adjustment in planning the activity from the beginning till the end because the implementation exceeds the planned time. At the end of the dialogue, the teacher provides the research schedule and direction to improve the RPP. Researchers realized that some obstacles were found in making learning plan. The constraints consist of: (1) adjusting the time from start to the end of activities; and (2) arranging the steps in the core activities of learning. In addition, the author met one of the mathematics lecturer to submit the RPP to be validated. The authors got directions to better explaining the indicators of competencies achievement, step on the core activities and replace some sentences on 
daily test questions (final test) in order to be well understood by students. Then researchers revised the section and got RPP validation with an average value of 4.4 from the average value of 5 and declared valid for use.

Student learning activities in this research is known in the learning process with learning in groups using student observation sheets. Study groups were formed from students with different abilities which were 7 groups. Student learning activity research was conducted only in 3 groups selected randomly as the subject. The subjects of this study were 14 students. The following is the description of student learning activities during the learning process that was then directly analyzed and categorized as follows;

Table 1. Student Learning Activity Percentage

\begin{tabular}{|c|c|c|c|}
\hline \multirow{2}{*}{ No. } & \multirow{2}{*}{ Indicators } & \multicolumn{2}{|c|}{ Meeting } \\
\hline & & 1 & 2 \\
\hline \multicolumn{4}{|c|}{ Observing } \\
\hline 1 & Paying attention to the material presented by the teacher & $77,1 \%$ & $81,4 \%$ \\
\hline 2 & Recording important information related to the material & $78,6 \%$ & $80 \%$ \\
\hline \multirow[t]{4}{*}{3} & Paying attention to the division of groups that have been & $78,6 \%$ & $77 \%$ \\
\hline & Average & $78,1 \%$ & $79,5 \%$ \\
\hline & & (B) & (B) \\
\hline & Asking & & \\
\hline 4 & Asking friends or teachers about unfamiliar material & $80 \%$ & $81,4 \%$ \\
\hline 5 & Arguing while discussing & $78,6 \%$ & $75,7 \%$ \\
\hline \multirow[t]{4}{*}{6} & Responding to friends' opinions when expressing opinions & $81,4 \%$ & $77,1 \%$ \\
\hline & Average & $80 \%$ & $78,1 \%$ \\
\hline & & (B) & (B) \\
\hline & Reasoning & & \\
\hline 7 & Searching deeply information related to material & $70 \%$ & $72,8 \%$ \\
\hline 8 & Discussing and analyzing the problem & $71,4 \%$ & $74,3 \%$ \\
\hline \multirow[t]{4}{*}{9} & $\begin{array}{l}\text { Conducting an experiment to find out the truth of the given } \\
\text { problem }\end{array}$ & $72,8 \%$ & $77,1 \%$ \\
\hline & Average & $\mathbf{7 1}, 4 \%$ & $74,8 \%$ \\
\hline & & (B) & (B) \\
\hline & Trying & & \\
\hline 10 & Reading information from other resources & $62,8 \%$ & $65,7 \%$ \\
\hline 11 & $\begin{array}{l}\text { Doing the on the exercises provided by teacher to solidify } \\
\text { the concept }\end{array}$ & $75,7 \%$ & $78,6 \%$ \\
\hline \multirow[t]{4}{*}{12} & Writing down the group work & $77,1 \%$ & $74,3 \%$ \\
\hline & Average & $71,9 \%$ & $72,8 \%$ \\
\hline & & (B) & (B) \\
\hline & Game & & \\
\hline 13 & Joining the game enthusiastically & $70 \%$ & $71,4 \%$ \\
\hline 14 & Working on the problem with the ability owned & $74,2 \%$ & $75,6 \%$ \\
\hline \multirow[t]{3}{*}{15} & Not bothering friends or cheating & $72,8 \%$ & $74,3 \%$ \\
\hline & Average & $72,4 \%$ & $73,8 \%$ \\
\hline & & (B) & (B) \\
\hline
\end{tabular}




\section{Tournament}

16 Joining the game enthusiastically

17 Working on the problem with the ability owned

$70 \% \quad 71,4 \%$

18 Not bothering friends or cheating

$75,8 \% \quad 75,8 \%$

Average

$74,3 \% \quad 72,8 \%$

$73,3 \% \quad 73,3 \%$

(B)

(B)

\section{Communicating}

19 Summing up the results of the discussions in written form

20 Presenting the results of discussions that have been implemented

21 Containing the conclusions of the material being studied together with the teacher

\section{Average}

Notes:

B: Good

Based on table 1, it can be seen that aspects of observing, asking, reasoning, trying, games, tournament, and communicating the grade 8.5 students of SMP Negeri 5 Malang are in good category. Here is an analysis of each aspect of student learning activities consists of 7 aspects with 3 indicators of each.

\section{Aspect of Observing}

The observing aspect consists of three indicators. These three indicators will be translated through the following elaboration.

a. Paying attention to Master's Submissions

At the first and second meetings, it appears that there were 2 (two) students who did not pay attention to the material provided. It shows that there are still students who tend to ignore the material provided. The teacher does not know exactly why they are not paying attention to the material and the teacher only gives a reprimand to focus on the material presented.

b. Recording important material related to Relevant Information

In the first and second meetings, students recorded the material in order and complete. It indicates that recording is routin activity done by the students. Without taking notes, students will forget the material they have learned, while by noting the students can learn to understand the material well, let alone written in the words they understand.

c. Paying attention to the Division of Groups that have been Set by the Teacher At the first and second meetings after the material, the teacher gave instructions to count from 1-7 to facilitate the division of the group. Students listened carefully to the instructions conveyed by the teacher. Then, students counted in sequence numbers 17. Teachers provide direction to form groups according to their respective serial numbers and sit in a place that has been determined by the teacher. 


\section{Aspects of Asking}

The asking aspect consists of three indicators. These three indicators will be translated through the following elaboration.

a. Asking Friends or Teachers about Undisclosed Materials

At the first meeting, one of the students raised his hand to ask the unknown matter. The student asked teacher the types of Opportunity and its differences. Teachers only provided answers to the various course and the difference, the students were given direction to keep paying attention to the teachers explanation and finding its own differences. Another example can also be seen from one group asking the teacher. At the second meeting, one student asked whether the writing of the experimental conclusions they have made is appropriate. The teacher checked the conclusion till the conclusion is correct and do not need to be replaced or added.

b. Giving opinions on Discussing

In the first and second meetings, not all groups could interact well, this was caused by people who like to stay and wait for the friends work and also busy asking to other groups.

c. Responding to Friends' Opinion When Issuing Opinions

Similarly with the 2nd indicator, the first and second meetings did not look good because the process of giving opinion is not going well.

\section{Aspects of Reasoning}

The reasoning aspect consists of three indicators. These three indicators will be translated through the following elaboration.

a. Digging Related Information

In the first and second meetings, students read the book to find out how to answer the given question. The questions given were in the form of description of the Worksheet (LKK).

b. Discussiing to Analyze Problems

At the first and second meetings, students discussed well. The teacher tried to come to one of the groups to observe the discussion process, 2 students were aware and the atmosphere was gone awkward where the other members were no longer continuing the discussion. Teachers assumed that students were embarrassed to discuss when the teacher i accompanying them.

c. Conducting an Experiment to Know the Truth Problems Provided

In the first and second meetings, students conducted an experiment to find out the truth of the problems given in the LKK. Then, the results of these experiments was seen in the experimental results they did in groups. The results of these experiments showed that students had experimented and got different results with other groups. The experiment was conducted to find out the empirical opportunity of an event. Opportunities made by a student in the experiment must have a different opportunity value.

\section{Aspect of Trying}

The trying aspect consists of three indicators. These three indicators will be translated through the following elaboration.

a. Reading Information from Other Resources 
In the first and second meetings, the teacher gave directions to read the material in another reference. Some students immediately asked whether they can use mobile phones, and teachers allowed it. Observer found there were 4 students using mobile phone for chating and playing games. Hearing the report, the teacher immediately gave directions to include handpone so that students were more focused with learning. Considering that students did not have books other than the package books they have, students find it difficult to find references from other sources. The incident happened in every meeting.

b. Working on Problem Exercises given by teacher to Establish Concepts

In the first and second meetings, teachers provided LKK to be done in groups, teachers also provided direction to each student to work on the matter in their respective notebooks. The activity aimed to anticipate the sense of students laziness and stimulate students to release the capabilities possessed so that these activities can avoid the nature of individuals in working on LKK given.

c. Writing Group Results

At the first and second meetings, students did the LKK that has been given. The LKK consisted of 3 description questions. All the groups wrote well the results of the discussion. The teacher tried to re-check and got 2 groups who wrote the wrong answers.

\section{Game Aspects}

The game aspect consists of three indicators. These three indicators will be translated through the following elaboration.

a. Joining the Game enthusiastically

At the first meeting, students were confused of the learning process. Many obstacles encountered, ranging from the struggle to be a reader about, the process of work that is not in accordance with the time set which was for 2 minutes, and the reader did not control the time in the problem process. Although some obstacles appeared, students still did not feel burdened by the process of the game. The game was done enthusiastically. Furthermore, at the second meeting, students could already adapt the rules of the game set. Even students felt less to the problem given as many as 6 problems because there were 12 problems to be done at the first meeting. Teachers did the same thing to other groups to check the enthusiasm of students in doing the game.

b. Working on the problem with the ability owned

At the first and second meetings, the game results were recorded on the scoreboard that has been given. The score showed different results. It showed that the students actually did the game in accordance with the ability they have. The score indicated that there were differences indicating the level of students' ability. The results were used by teachers to facilitate the division of students in following the tournament.

c. Not bothering friends or cheating

In the first and second meetings, students enthusiastically participated in the game even not infrequently some students interfered with friends by making jokes and speeding up the time for other students can not do the problem. Not cheating activity was found because students work on the game in accordance with their own ability. The results of the scoreboard will be the same if the cheating happened. 


\section{Aspects of Tournament}

The tournament aspect consists of three indicators. These three indicators will be translated through the following elaboration.

a. Joining the Game enthusiastically

This activity was the same as in game implementation. At the first meeting, many students complained of having the same thing as games though with different groups. Students feel objected and some feel this activity was in vain because they have to work on the problem again with impossible conditions that the lesson time is almost done. Indeed teachers understand about it, the teacher gave an explanation that students must implement the tournament because it has become part of the learning activities. Students tried to work and enthusiastically following the tournament although some students were meaning to immediately end the activity due to the break time. This enthusiasm is because they have been competing with friends from different groups and raising a sense of wanting to show the greatest. The results of the scores obtained can show which group was best. Scrambling to answer questions was inevitable. At the second meeting, students could already understand why tournament activities should be held after the game activities. Teachers were very easy at controlling this activity rather than in the first meeting.

b. Working on the problem with the ability owned

At the first and second meetings, the scores obtained by the students were written on the scoreboard given. The score showed different results. It showed that the students really did the tournament problem in accordance with their ability. The score indicated that there were differences that can indicate the level of ability students have.

c. Not bothering friends or cheating

At the first and second meetings, students enthusiastically followed the tournament, even not infrequently some students interfered with friends by making jokes and speeding time to make them can not do the same as the game implementation. No cheating activity was found because students work on the game in accordance with their own ability. The results of the scoreboard will be the same if the cheating happened.

\section{Aspects of Communicating}

The communicating aspect consists of three indicators. These three indicators will be translated through the following elaboration.

a. Summing up the results of the discussions in written form

At the first and second meetings, students concluded the results of the discussions they have made. Indeed not all groups can write well the conclusions they got. There were also groups that did not write the conclusions they got.

b. Presenting the results of discussions that have been implemented

At the first meeting there were 3 groups while the second meeting were 2 groups that presented the work/ of the group. In the first meeting presentation, there were 2 (two) groups presenting the results that were still less precise, the results in the form of writing the sample space of events in the LKK so that it took 1 (one) more group to improve the writing of the sample space. In the second meeting presentation, the teacher appointed 2 (two) groups to present the results of the discussion. This was based on the discussion of the LKK that required students to experiment on throwing coins. The results of the presentation showed that each experiment conducted by each 
group would get different results because the opportunity itself was the possibility of each event.

c. Containing the conclusions of the material being studied together with the teacher

At the first and second meetings, the teacher had a conversation with the students about the material they have learned. Some students were able to give conclusions about the material being studied. The process showed that during learning activities, some students were are able to understand the material well.

Student learning outcomes in this research was in the form of final test results after the end of learning activities and become a reference as a complete learning of students. The table below represents the percentage of individual student learning outcomes achievement.

Table 2. Individual Completeness

\begin{tabular}{ccc}
\hline $\begin{array}{c}\text { Number of } \\
\text { Students }\end{array}$ & Percentage & Explanation \\
\hline 28 & $82,3 \%$ & Completed \\
6 & $17,7 \%$ & Uncompleted \\
\hline
\end{tabular}

The table below is the percentage of learning mastery achievement in classical.

Table 3. Classical Exhaustiveness

\begin{tabular}{ccc}
\hline $\begin{array}{c}\text { Number of } \\
\text { Completed } \\
\text { Students }\end{array}$ & $\begin{array}{c}\text { Number of } \\
\text { Students }\end{array}$ & $\begin{array}{c}\text { Classical } \\
\text { Exhaustiveness }\end{array}$ \\
\hline 28 & 34 & $\frac{28}{34} \times 100 \%=82,5 \%$ \\
\hline
\end{tabular}

Table 3 is a complete student learning table. Based on the above table, from 34 students who take the test, 28 students have minimum achievement for $80 \%$. Based on the criteria set, the 28 students are individually having complete learning, while 6 students were not complete the study because it has not reached a predetermined standard. Based on the standard set in SMP Negeri 5 Malang, it is classically have to reached $80 \%$ completenes. Table 4 shows that the percentage of achievement is $82.5 \%$ classical and can be said to be complete because the percentage has reached a minimum of $80 \%$. This is supported by the results of previous research which stated that the result of students learning mathematics by applying cooperative learning model type TGT with scientific approach had reached minimum standard (Ramadhana, 2015).

\section{CONCLUSION}

Researchers designed TGT activities focused on 4 components: (1) presentation in class, (2) team, (3) game, and (4) tournament. This is based on the learning time at the school which has 40 minutes at each meeting and the TGT activities must be combined with a scientific approach that has 5 activities, are (1) observing, (2) asking, (3) trying, (4) reasoning, and (communicating). The planning process met the constraints of adjusting the time from the beginning to the end and preparing the steps in the core activities of learning. At the time of the validation process, the planning that has been made was 
corrected and improved to better explaining indicators of achievement competency, step on the core activities, and replace some sentences on test questions to be well understood by the students. The process of learning through the TGT model with a scientific approach had worked well. The results showed that student learning activities through the application of cooperative model type TGT with scientific approach on the material Opportunity at class VIII in SMPN 5 Malang class 8.5 was in "good" category. The results obtained were 28 complete students and 6 uncompleted students. The students' completeness was based on the school's KKM that has achieved the score of $\geq 80$. Classically, the students' completeness reaches $82.3 \%$ and was said to be complete because they had achieved classical completeness at school by $\geq 80 \%$.

\section{REFERENCES}

Lampiran Permendikbud Nomor 103 Tahun 2014 Tentang Pembelajaran pada Pendidikan Dasar dan Pendidikan Menengah. Jakarta: Unpublished

Ramadhana, Rizky. 2015. Penerapan Model Pembelajaran Koperatif Tipe TGT (Teams Games Tournament) dengan Pendekatan Saintifik Terhadap Hasil Belajar Matematika. Jurnal Prosiding Seminar Nasional. 02 (1): 418-420.

Rusman (2012). Model-model Pembelajaran: Mengembangkan Profesionalisme Guru. Jakarta: PT Raja Grafindo Persada.

Slavin, R. E. (2009). Cooperatif Learning. Bandung: Nusa Media.

Sudarti (2015). Peningkatan Prestasi Belajar IPS Melalui Team Games Tournament (TGT) di Kelas V SD NEGERI 1 Gemaharjo Kecamatan Watulimo Kabupaten Trenggalek. Jurnal Pendidikan Profesional Vol. 4, No. 2, 179.

Yuhasriati. 2012. Pendekatan Realistik dalam Pembelajaran Matematika. Jurnal Peluang Vol. 1, No. 1, 81. 